\title{
ENHANCING ONLINE STUDENT ENGAGEMENT WITH EXTRACURRICULAR ACTIVITIES
}

\author{
Tina Burton, Purdue University Global, tburton@purdueglobal.edu \\ Rhonda Chicone, Purdue UniversityGlobal, rchicone@purdueglobal.edu \\ Susan Ferebee, Purdue UniversityGlobal, sferebee@purdueglobal.edu
}

\begin{abstract}
Engaging non-traditional, adult, online students can be a challenge, but a variety of extracurricular activities can serve to increase their interest in their education and enhance their learning. Lacking the opportunity for 'on-campus' interactions and the traditional 'Student Union' environment, online universities must provide virtual environments that invite collaboration and extracurricular activities that support student interaction and engagement. The use of content related clubs that include faculty mentors, subject matter experts, and interactive activities can be effective. The introduction of competitions and game play related to coursework can also provide the desired engagement and commitment to the academic programs and institution. The rapidly growing industry of EdTech supports the agenda of all educators who seek these innovative ways to engage and impart knowledge to a diverse population of learners.
\end{abstract}

Keywords: Engagement, extracurricular activities, student clubs, competitions, EdTech

\section{INTRODUCTION}

Maintaining and increasing student engagement is challenging under any circumstances but doing so in the online environment with non-traditional students can be particularly difficult. A wide variety of strategies must be employed to maximize the engagement and reap the benefits associated with higher levels of engagement, particularly retention, student commitment to the institution and program, as well as higher levels of academic performance (DeVito, 2016; Kahu, 2013). This study seeks to explore the types of student engagement that are most common and the perceived benefits of this engagement on academic performance as well as to student commitment.

The online education environment allows a wider variety of students to obtain their college education and enables working adults, as well as straight out of high school students to enjoy the freedom of completing their studies virtually, and in a mostly asynchronous format. This allows a greater number of students to fit the educational process into their busy lives, often with restricted resources and minimal flexibility (Gillingham \& Molinari, 2012). Generally online education particularly appeals to non-traditional students, who are defined as those who might be older than the typical college applicant and who might also enter the education process with additional obligations both financially and in reference to familial responsibilities (Cross, 1980). Non-traditional students often require additional support to build their confidence about entering or re-entering the academic environment and seek to work together with their peers to refresh study skills and learning how best to apply their work and life experiences (Benshoff \& Lewis, 1992; Gillingham \& Molinari, 2012; Muench, 1987).

Determining strategies to enhance engagement for this unique population takes effective use of technology as well as the dedication and creativity of faculty and administrators of any educational institution (Gillingham \& Molinari, 2012). Whereas traditional students may live on campus, or remain on campus beyond attending courses, engage in academic and sports activities conducted locally, and in general maintain a social presence with their classmates and faculty, the non-traditional students attending online have none of these options. However, this does not make the concept of engagement absent in this environment, it merely takes greater planning, thought, and sometimes resources to be successful.

Extracurricular Activities Available to Online Students

As with traditional universities and students, academic student clubs are one option for online students as well. Clubs that focus on specific programs of study or areas of interest can be an effective engagement tool for institutions. For example, having a Cybersecurity or Accounting club can bring together students in those particular programs where they can partake in conversations and activities with like-minded students in their program. The use of guest speakers 
from the faculty or industry partners are a great way to get students enthused about concepts they are learning within their courses.

Another innovative option for some students might be academic competitions or contests. In this case, it can be appealing to conduct a research contest where student work can be presented and evaluated by faculty and student peers for an 'award' or recognition. Another increasingly popular idea is the concept of a Capture the Flag (CTF) competition for IT and Cybersecurity students where they can compete and demonstrate their skills in a game-like environment (Chicone, Burton, \& Ferebee, 2017). It is a critical aspect of learning in the field of cybersecurity to experience "hands-on" activities that allow students to learn advanced problem-solving skills (Yuan, 2017). Recognizing the need and value for hands-on activities as part of cybersecurity curriculum, the concept of gaming has been explored by many academic institutions and educational entities that support these academic programs.

\section{The EdTech Industry}

In support of the idea that activities outside the classroom can enhance program commitment, student persistence and academic performance, the growing EdTech industry provides institutions with a wide variety of options to explore. The industry is booming with new entrants that bring wildly innovative products, platforms and programs of all kinds (Butcher, 2018). New startups in this field are changing the face of education worldwide and opening new opportunities for the truly non-traditional student; those who might otherwise never even realize the possibility of a college education. The industry is also unique in that it receives nearly unlimited funding both from the government and private sector (Pozin, 2015). As universities broaden their scope to admit and serve more non-traditional universities, this industry will provide the innovation to keep them engaged, regardless of their economic backgrounds, countries of origin, or educational preparedness.

The EdTech industry's top trends tend to vary depending on who is asked but most experts agree the list includes creativity, more data driven decisions, greater accessibility, a better understanding of students' needs for a healthy wellbeing and an integrated learning experience overall (Singh, 2018). One innovative product designed in the EdTech industry to make use of student clubs and their members is called Door of Clubs. Whereas the traditional job fairs tend to be less than successful venues to fill all the positions companies have available, the Door of Clubs platform connects students with company recruiters directly on a virtual platform. Employers have found that student clubs are filled with ambitious, dedicated and curious students who can greatly enhance the hiring pool of candidates. The service is free to students and employers pay small monthly fees to be able to search and make contact with students. Door of Clubs also helps to remove the geographical barriers that exist with the traditional job fair model (McNeal, 2016).

\section{RESEARCH METHODOLOGY}

This qualitative, exploratory research study is centered upon the following two research questions:

1. Do students perceive that participating in extracurricular activities increases their engagement with school?

2. Do students perceive that participation in extracurricular activities is beneficial (or adds value) in their program of study?

This study included a qualitative survey about the students' participation in extracurricular activities during their current programs and their perceived self-reported engagement as a result of their participation. Student engagement is a widely studied concept and can be defined by the level of involvement or interest students have in their programs of study and their institutions in general. Additionally, student engagement can refer to the level of connection students feel to their programs, institutions, and fellow students (Axelson \& Flick, 2011). The survey sought to gather this type of information and determine students' perception of the effects of the extracurricular activities, as well as the factors that inspired them to participate or not, in the activities available. Demographic information was collected to assess the level of extracurricular participation across various degree levels, age groups, and genders. All students currently enrolled in the business and IT programs, at all levels, were invited to participate. 


\section{Issues in Information Systems \\ Volume 19, Issue 3, pp. 202-211, 2018}

\section{RESULTS}

A survey was sent to 2110 college students in the business and IT programs. Within the short timeframe for completion allotted, the researchers received 73 consent forms and completed surveys. The survey included a total of 10 questions and the first four questions were regarding the students' demographic information. The gender of all participants was nearly 50-50, with 38 female respondents and 35 that were male. The additional demographic results of the survey were diverse as well and shown in Figures 1-3.

Degree all Participants

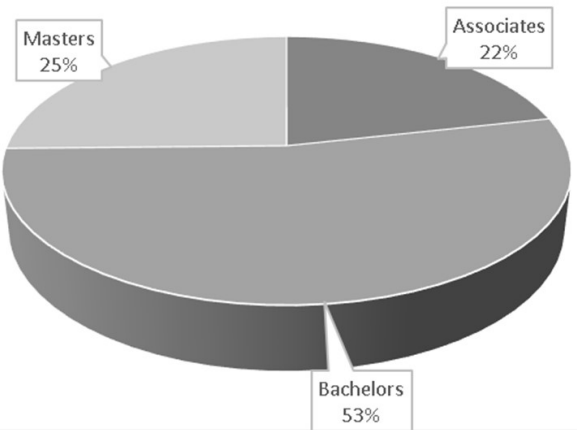

Figure 1. Participants by Degree Level

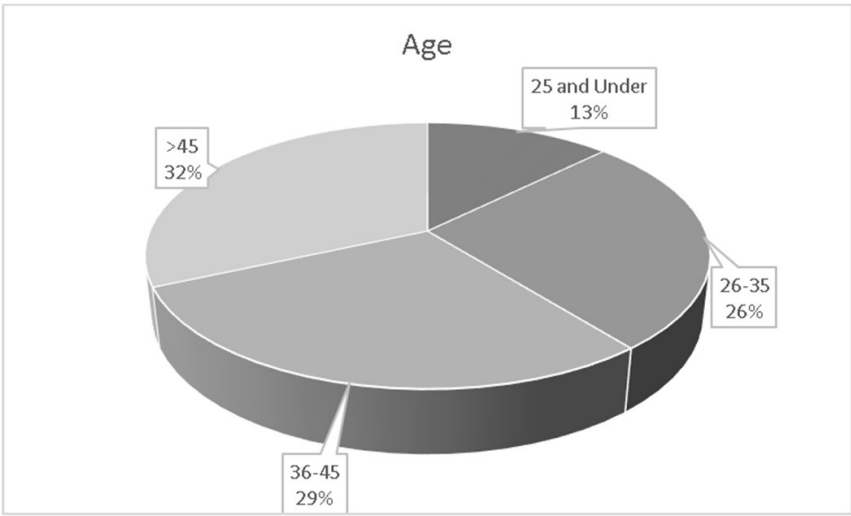

Figure 2. Participants by Age Group

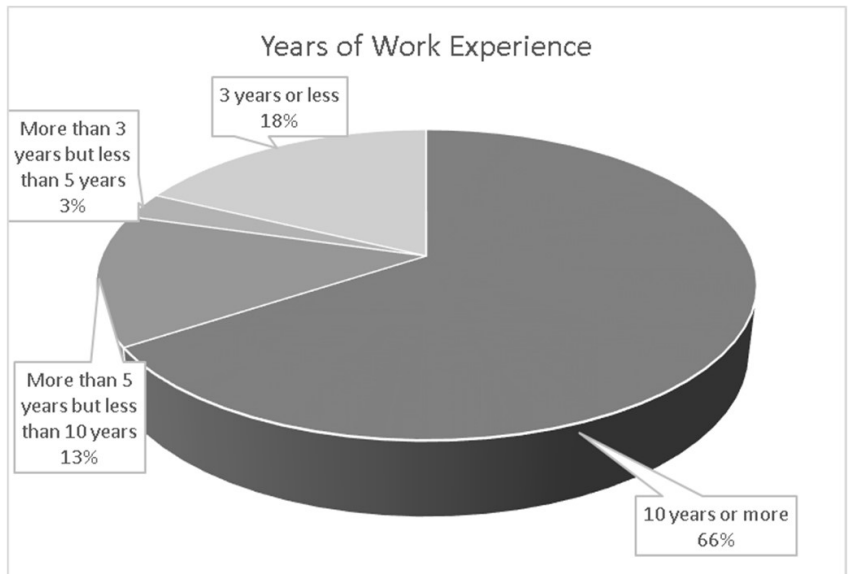

Figure 3. Participants' Work Experience by Years 
The next six questions on the survey were specifically in reference to the students' participation or lack thereof, in extracurricular activities. If they answered yes to having participated, they were further asked about their experience and the possible affect that had on their commitment to the university and/or their program of study, as well as the impact the activities may have had on their programmatic skill set. If the participants answered no to the initial question about participation, they were asked for reasons why they did not participate. All respondents were also asked for final thoughts on extracurricular activities in general, their interest in new opportunities, or the overall impact of these activities on their educational experience.

The first remarkable and unexpected result of the survey was the high percentage of students who responded that they had not participated in any extracurricular activities during their current educational program; $80 \%$ responded no to this inquiry. This was disappointing due to the impact on the study sample, but provided invaluable insight to the researchers. In addition, the most common reason why they did not participate was because they were not aware of the activities; over half of those that did not participated selected this response. This definitely provided the researchers with an important action item. While the university publicizes the clubs and related activities on its external web site, on the student portal when the students log into class, and in classroom announcements, clearly this is not sufficient to make students aware of the opportunities. An increase in awareness could dramatically affect the positive results available to students who engage in extracurricular activities.

Another significant result is that a good portion of the students perceived a lack of time to participate in these activities. Hopefully with greater awareness of the flexibility and optional nature of the activities this perception can be changed. Participation time commitments don't have to be significant to generate value and students need to be informed of that flexibility. Figure 5 displays the reasons for not participating in the extracurricular activities; the small percentage of students who selected 'no interest' is a positive indication that the majority of the students surveyed see some value in participating.

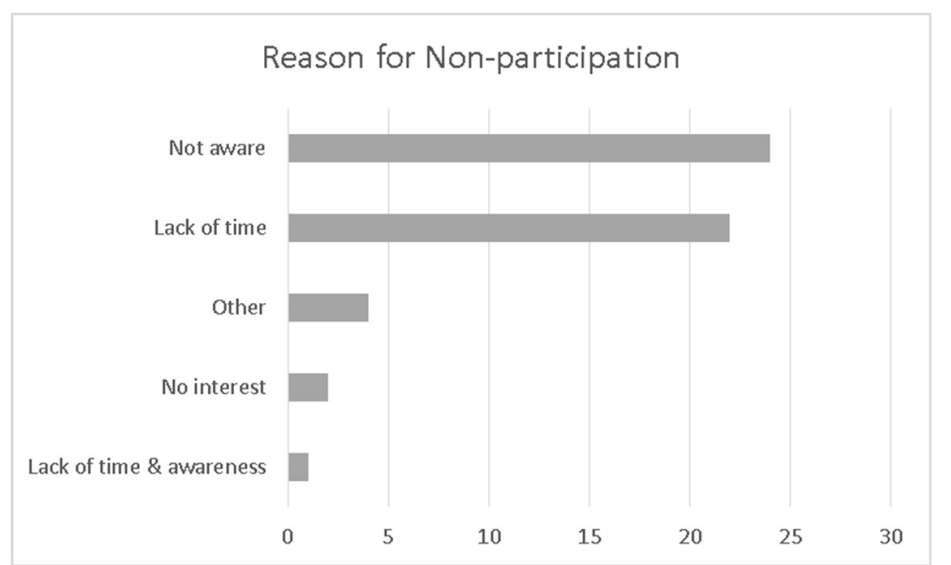

Figure 5. Reasons reported for not participating in extracurricular activities

Further analysis was done to assess the results of the smaller group who did respond yes to participating in some form of extracurricular activity. Figure 6 displays the gender and age groups represented by those that did participate in extracurricular activities. 


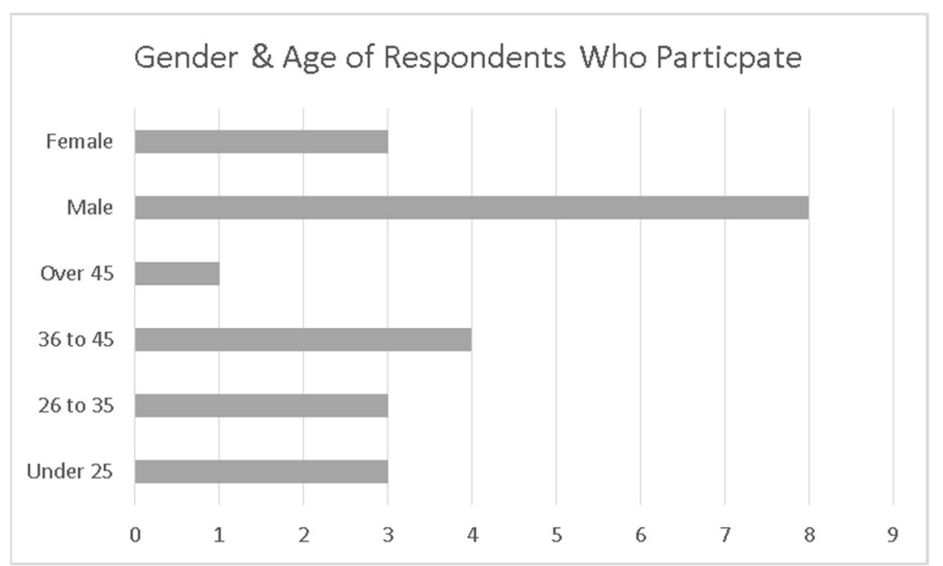

Figure 6. Gender and age of respondents who participated in extracurricular activities

As Figure 6 indicates, the majority of participants were male. Based on the greater number of clubs and activities associated with the IT programs, and the higher male enrollment in IT programs (Catalyst, 2018), this was not a surprising result. The two younger age groups, representing those under 35 produced the greatest number of participants. This may align with the Millennials' need to connect and be involved (Elam, Stratton, \& Gibson, 2007; Landrum, 2018). Overall the age and gender demographics tend to represent the norm for the University, specifically in IT programs (Kaplan, 2017).

The degree level of those who responded yes to participating did vary but the results indicate that the most common level of participants was at the bachelor degree level; see Figure 7. It is likely that the Associates level students are not yet accustomed to the standard commitment of time to add to that extracurricular activities, and that graduate level students see less value in the extracurricular activities at their level. These assumptions would need further research to be conclusive.

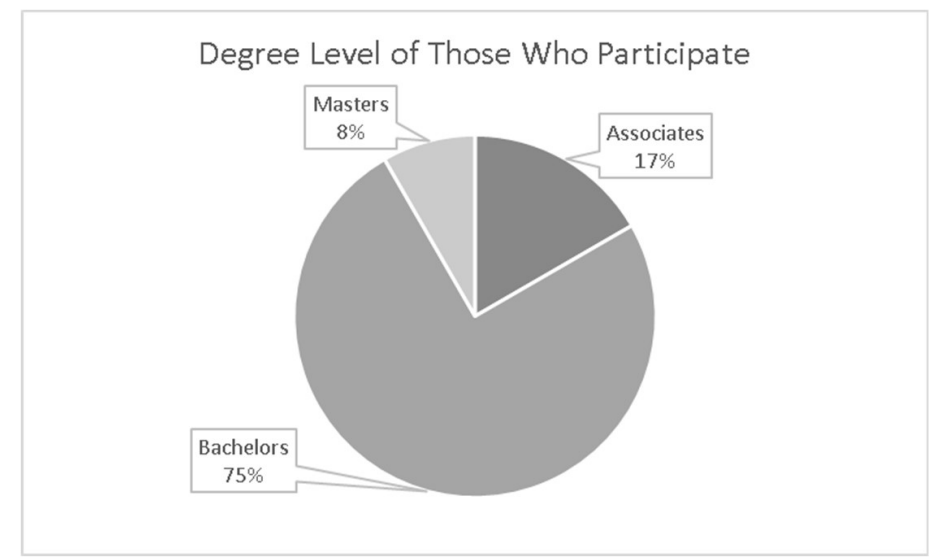

Figure 7. Degree level for students who participated in extracurricular activities

The types of activities were classified into five categories Honors, Lifestyle, Military, School Subject, and Professional. The types of activities that students indicated they participated in varied widely between the five categories but $30 \%$ of the participants identified with an activity classified as 'School Subject'. As might be expected, those that indicated they participated in the school subject, professional, and honors activities also indicated that their interest in school and academic program skills were enhanced, with the school subject activities showing strong for both general school interest and program interest. For increasing commitment, military and lifestyle activities also were stated to increase their commitment but not necessarily their interest in school or their program.

The comments related to the questions about enhanced commitment to the program and school, as well as increasing the interest in and the enhancement of skills related to the academic program are in Table 1 . The comments definitely reinforced the positive effect that results from extracurricular activities. 
Table 1. Responses related to commitment and skill enhancement

\begin{tabular}{|c|}
\hline Comments \\
\hline It gave me a chance to have a hands experiment. \\
\hline Peaked interest in expanding in field. \\
\hline $\begin{array}{l}\text { I feel both the club and the events held by them have helped me to expand my understanding of a variety of } \\
\text { subjects; as well as introducing me to areas my studies and degree plan hasn't yet. }\end{array}$ \\
\hline Being a part of the ACM helped strengthen my interest in website building, and software development. \\
\hline I got to be more involved in something I was interested in. \\
\hline Makes participation in school enjoyable when you can connect outside the online classroom. \\
\hline Made me want to be part of this school. \\
\hline I feel like some side projects help me to stay focused on the bigger picture and end goal. \\
\hline I have surrounded myself with a great group of people that are very supportive \\
\hline $\begin{array}{l}\text { I have developed a sense of welcoming and ownership with the school. When a person chooses a color and paints } \\
\text { a wall, they feel accomplishment because it's their color choice, work, and accomplishment. Extracurricular } \\
\text { activities provide a means for students to paint their wall. }\end{array}$ \\
\hline It helped out as community work. \\
\hline I looked forward to working with professors and other students. \\
\hline It helped me think on my feet more. \\
\hline Helped me learn more about security and safety online. \\
\hline I am learning about things that I would not have found out until I got into the work force. \\
\hline $\begin{array}{l}\text { I think of the events I have participated in thus far, I have gained a more clear understanding of some of the } \\
\text { information I had already covered. I think the sort of review testing events have allowed me to see just how well I } \\
\text { truly understand what I have learned. }\end{array}$ \\
\hline I believe that they have enhanced my understanding of website development and maintaining websites. \\
\hline $\begin{array}{l}\text { Personally I think I am the only one participating in the Cloud Club but I get to do things that interest me. We did } \\
\text { have the chance to work with another club but I am not the president and have not seen anything come from this. }\end{array}$ \\
\hline I felt more involved with the school and that the school was more involved with me. \\
\hline $\begin{array}{l}\text { Participation in these groups and clubs help to keep me up-to-date with trends of my academic program. They } \\
\text { also helped network with a wide variety of my peers with similar career goals as myself, which helped in my } \\
\text { commitment to Purdue Global and my program. }\end{array}$ \\
\hline $\begin{array}{l}\text { My extracurricular activity is technology based and so is my area of study. Participating in PGACM-W has } \\
\text { allowed me to actively celebrate women in IT and become part of that community. }\end{array}$ \\
\hline $\begin{array}{l}\text { The groups and clubs I am in help build leadership skills, professional development through educational } \\
\text { resources and networking, and helped me recognize the areas within my field that I excel at, as well as, the areas I } \\
\text { need to improve on. }\end{array}$ \\
\hline
\end{tabular}

The data in Table 1 can be used to establish common themes for defining the positive effects on commitment via extracurricular activities. The most common and significant words used in the responses are 'interest' and 'learning'. An enhanced interest in a subject or academic program can aid students in achieving their academic goals (Harackiewicz \& Hulleman, 2010).

Another significant theme was related to the words and phrases 'involved', 'community', 'being a part of' that were noted multiple times. These words indicate the importance for students to have a sense of community and belongingness within their academic institution, which has a positive effect on their overall happiness and satisfaction with their school and program (Civitci, 2015). Astin (1993) found that students' interaction with their peers enhanced their leadership and overall academic development, and improved their problem-solving skills, and critical thinking skills.

In response to the final question, asking for additional thoughts on extracurricular activity participation overall, the comments shared are in Table 2. Comments from those who participated in extracurricular activities and those that did not are included. All comments have been included 'as is' and only edited to remove specific school names or references. 
Table 2. Responses to final question from all respondents

\begin{tabular}{|c|c|}
\hline $\begin{array}{l}\text { Participated } \\
\quad \text { Y/N }\end{array}$ & Comments \\
\hline No & $\begin{array}{l}\text { I work } 12 \text { hours a day six to seven days a week. If I had time to take part in extracurricular } \\
\text { activities I would do it. }\end{array}$ \\
\hline No & $\begin{array}{l}\text { I work full time and trying to balance work, school and life, I haven't found any extra time to } \\
\text { commit to extracurricular activities. }\end{array}$ \\
\hline No & I intend on joining some clubs I just don't have the time at the moment. \\
\hline No & I would be interested in activities but have not been made aware of any. \\
\hline No & $\begin{array}{l}\text { I would like to do extracurricular activities, just don't have time during this term as I am taking } 3 \\
\text { classes, working full time and having a baby at home. When this term is complete I plan to get } \\
\text { back in to taekwondo. }\end{array}$ \\
\hline No & I've always heard of hazing and such things. \\
\hline No & Excited to see. \\
\hline No & $\begin{array}{l}\text { I think sending out emails, letting students know what extracurricular activities are available. I } \\
\text { think having extracurricular activities in the major a person is taking would be great. }\end{array}$ \\
\hline No & $\begin{array}{l}\text { I am a full time Mom, Employee and student - pretty much like most or all students that fit the } \\
\text { profile of a mature person that is trying to balance a number of responsibilities on a day to day } \\
\text { bias. With that in mind, I am not sure how much time I would have to dedicate to extracurricular } \\
\text { activities for school; however, if what is being proposed can help to enhance the learning process } \\
\text { or can help greatly in my personal development and growth, then I may be inclined to sign up for } \\
\text { at least one activity. }\end{array}$ \\
\hline No & $\begin{array}{l}\text { I think student engagement is instrumental to student success. I would love to know about } \\
\text { student engagement activities available for online program learners. }\end{array}$ \\
\hline No & $\begin{array}{l}\text { I think that extracurricular activities are good if they are focused on the field of study. An } \\
\text { example would be a SQL club to hone SQL skills with classmates, or a club where students from } \\
\text { the same degree program or area of study can share knowledge on IT subjects. }\end{array}$ \\
\hline No & $\begin{array}{l}\text { I worked a full time job and go to school in the evenings, My main focus is on getting my } \\
\text { degree. }\end{array}$ \\
\hline No & $\begin{array}{l}\text { Not sure what type of activities are available or how they may add value to my learning } \\
\text { experience. However, I do think that being part of a study group or students with similar interest } \\
\text { will increase my engagement in school. }\end{array}$ \\
\hline No & If time between studies and work would permit, I would be interested in these types of activities. \\
\hline No & $\begin{array}{l}\text { It's difficult to justify getting involved in extracurricular activities in an online program. The } \\
\text { purpose of the online program is to be flexible and help accommodate a busy lifestyle. To make } \\
\text { time for extracurricular activities, over other activities that are family, friend, or career related } \\
\text { (such as pursuing certifications) is a difficult ask. The activity must warrant the time and } \\
\text { financial investment and the ones I have seen have failed to offer these incentives. }\end{array}$ \\
\hline No & $\begin{array}{l}\text { I want to become more active in extracurricular activities, as in joining clubs (I have not heard a } \\
\text { response back from clubs I have requested to join, I've tried on numerous occasions), an } \\
\text { association and I want to become a part of the student advisory board one day. }\end{array}$ \\
\hline No & I would be interested if I had more time. \\
\hline No & I hadn't checked or didn't know what activities were available. \\
\hline Yes & Extracurricular activities are very important for people in online programs to connect in person. \\
\hline Yes & I would like to participate in more of them. \\
\hline Yes & I wish there were more so we could interact with classmates more. \\
\hline Yes & I am glad as an online school we are still able to have these activities. \\
\hline Yes & $\begin{array}{l}\text { I have thoroughly enjoyed the events and club activities up to this point. I look forward to more } \\
\text { engaging and enhancing experiences in the future. I feel like these activities are a great } \\
\text { supplement to the current structure of my degree plan. }\end{array}$ \\
\hline Yes & $\begin{array}{l}\text { I was interested in getting my associates degree at first and I was in that program but recently, I } \\
\text { went and switched into the Bachelor's program and part of the encouragement was from some of } \\
\text { my peers and family. }\end{array}$ \\
\hline
\end{tabular}




\begin{tabular}{|l|l|}
\hline \multicolumn{2}{|l}{} \\
\hline Yes & $\begin{array}{l}\text { I can honestly say, that I have applied for a few other extracurricular activities, and never heard a } \\
\text { response back. I think there needs to be a response if we get accepted or denied. As it currently } \\
\text { stands, I submit a Google request form, and nothing happens. I'm assuming someone is supposed } \\
\text { to respond to the request, however they have not been doing that. This might be due to the clubs } \\
\text { not being formed, or email issue with the transition, but it's a problem that should be addressed } \\
\text { if the intent for extracurricular activities is to spread to other students. }\end{array}$ \\
\hline Yes & If the chance was available to get experience on the job I would do it. \\
\hline Yes & $\begin{array}{l}\text { I recently joined ACM in April. I joined as I felt that it would keep myself engaged with other } \\
\text { students and learn new things along the way. I do enjoy listening to guest speakers as it will help } \\
\text { me learn their roles in their careers and help me choose a path to go down, once I graduate. }\end{array}$ \\
\hline Yes & $\begin{array}{l}\text { I think clubs are an important piece of education it develops a team environment through } \\
\text { participation and discovery. }\end{array}$ \\
\hline No & I would be interested if I had more time. \\
\hline No & I hadn't checked or didn't know what activities were available. \\
\hline No & Being that I'm studying IT with an interest in Software dev/ maybe a coding study group \\
\hline No & Would like more information \\
\hline Yes & Extracurricular activities when tied to areas of study encourages growth. \\
\hline Yes & $\begin{array}{l}\text { Participation in extracurricular activities is a great way to build relationships with your peers. In } \\
\text { an online environment, it is sometimes hard to build relationships with people because we do not } \\
\text { physically see each other, but extracurricular activities provides a platform for students to further } \\
\text { develop these important relationships among like-minded students. }\end{array}$ \\
\hline No & They might help me connect with other students and develop a support system with them. \\
\hline
\end{tabular}

One particularly prevalent theme emerged in these comments and that is the factor of 'time'. The vast majority of responses made some reference to the lack of available time, the inability to make time, or the concern that they could not dedicate the expected amount of time necessary to participate. McMillan and Reed (2010) studied at-risk students in particular and noted that their effective use of time had a significant impact on their resiliency and academic persistence. Enabling students to better manage and use their time for meaningful activities is a great lesson to impart during extracurricular club activities.

As the comments in Table 2 also indicate, even those who have not yet been able to participate believe the activities could be beneficial and add to their academic experience. Some of the important phrases were 'engagement', 'personal growth', 'relationships'. As Montelongo (2002) indicates in his review of literature that summarizes the benefits of extracurricular involvement, such involvement has a significant positive effect on interpersonal and leadership skills and these enhanced skills lead to occupational success. Therefore, the participation in such activities can reach beyond academic success and support the desired career attainment as well.

Most of those who have not participated yet indicate an interest in learning more about the activities and being able to participate in the future. These comments were encouraging to the researchers and provide them with opportunities for expanding the extracurricular activities and participation. Some of the comments indicate a shortcoming in the registration process and those issues can now be fully addressed as well.

\section{CONCLUSIONS}

While the background research indicates the value associated with extracurricular activities in enhancing student engagement in their academic programs, and the results of this study confirm that indication, the sample size for this study was small and calls for future research. Unfortunately, the unexpected result of this study highlights the lack of participation and awareness in these opportunities is significant. However, the interest expressed for learning more indicates the school should improve its communication and marketing of the activities and create an action plan to engage more students.

One area that warrants additional research is the commitment piece, since that is likely to result in graduation and persistence, and this aspect is important for the school and was only minimally addressed in this study. Of those that participated in extracurricular activities, $67 \%$ did indicate a greater sense of commitment to the program and school and $50 \%$ indicated a greater commitment to their academic program of study. This clearly is an important positive effect that should be maximized by the University. 
Targeting the Associate's level students to engage in the extracurricular activities early on in their programs, based on their current lower level of participation, would be an important area of growth and additional research. An added benefit would be if extracurricular activities do more fully engage them, then they may continue to pursue higher degrees and complete at the Associate's level. These students who join and participate early in their program could be paired with new students to share their enthusiasm and sense that the clubs/extracurricular events have made a difference to them.

\section{REFERENCES}

Astin, A. W. (1993). What matters in college? Liberal Education, 79(4), 4-18. Retrieved from http://search.epnet.com/login.aspx?direct=true\&db=aph\&an=9409260313

Benshoff, J. M. \& Lewis, H. A. (1992). Nontraditional College Students. ERIC Clearinghouse on Counseling and Personnel Services Ann Arbor MI. Retrieved from https://www.ericdigests.org/1992-3/college.htm

Butcher, M. (2018). Ed Tech is having a renaissance powered by the emerging world. Retrieved from https://techcrunch.com/2018/03/18/edtech-is-having-a-renaissance-powered-by-the-emerging-world/

Catalyst.org (2018). Women in Science, Technology, Engineering, and Mathematics (STEM). Retrieved from http://www.catalyst.org/knowledge/women-science-technology-engineering-and-mathematics-stem

Chicone, R., Burton, T., Ferebee, S. (2017, October) Using Facebook's open source Capture the Flag platform as a hands-on learning and assessment tool for cybersecurity education. Proceedings of the International Association for Computer Information Systems, 57th International Conference, Philadelphia, PA. Retrieved from https://www.iacis.org/conference/proceedings/IACIS_2017_Proceedings.pdf

Civitci, A. (2015). Perceived stress and life satisfaction in college students: Belonging and extracurricular participation as moderators. Procedia-Social and Behavioral Sciences, 205, 271-281. Retrieved https://www.sciencedirect.com/science/article/pii/S1877042815050958?via\%3Dihub

Cross, K. P. (1980, May). Our changing students and their impact on colleges: Prospects for a true learning society. Phi Delta Kappan, May, 630-632.

DeVito, M. (2016). Factors Influencing Student Engagement. Unpublished Certificate of Advanced Study Thesis, Sacred Heart University, Fairfield, CT. Retrieved from http://digitalcommons.sacredheart.edu/edl/11

Elam, C., Stratton, T., \& Gibson, D. D. (2007, Spring). Welcoming a new generation to college: The millennial students. Journal of College Admission, 195, 20-25.

Gillingham, M. \& Molinari, C. (2012). Online Courses: Student Preferences Survey. Internet Learning, 1(1). Retrieved at http://digitalcommons.apus.edu/internetlearning/vol1/iss 1/4

Harackiewiczmm, J. M. \& Hulleman, C. S. (2010). The Importance of interest: The role of achievement goals and task values in promoting the development of interest. Social and Personal Psychology Compass, 4(1), 4252. Retrieved from https://psych.wisc.edu/cmsdocuments/CompassHH.pdf

Kahu, E. R. (2013). Framing student engagement in higher education. Studies in Higher Education, 38(5), 758-773, DOI: $10.1080 / 03075079.2011 .598505$

Kaplan (2017). Academic Report - Year in Review. Retrieved from https://www.purdueglobal.edu/academicreport.pdf

Landrum, S. (2018, January 19). Millennials are Happiest When They Feel Connected to Their Co-Workers. 
Retrieved from https://www.forbes.com/sites/sarahlandrum/2018/01/19/millennials-are-happiest-whenthey-feel-connected-to-their-co-workers/\#424f6c173a2f

McMillan, J. H., \& Reed, D. F. (2010). At-risk students and resiliency: Factors contributing to academic success. The Clearing House: A Journal of Educational Strategies, Issues and Ideas, 67(3), 137-140, DOI: 10.1080/00098655.1994.9956043

McNeal, M. (2016). To Find Diverse Talent, Some Companies Look to College Clubs. Retrieved from https://www.edsurge.com/news/2016-11-15-to-find-diverse-talent-some-companies-look-to-college-clubs

Montelongo, R. (2002). Student participation in college organizations: A review of literature. Journal of Indiana University Student Personnel Association. Retrieved from http://scholarworks.dlib.indiana.edu/journals/index.php/jiuspa/article/download/4617/4240

Muench, K. E. (1987, October). A comparative study of the psychosocial needs of adult men and women students in an adult degree program. Paper presented at the annual meeting of the American Association for Adult and Continuing Education, Washington, DC.

Pozin, I. (2015). 10 EdTech Companies you need to know about. Retrieved from https://www.forbes.com/sites/ilyapozin/2015/10/25/driving-innovation-10-edtech-companies-you-need-toknow-about/\#7fcd99a09482

Singh, A. (2018). Introducing the Top 8 EdTech Trends for 2018: Are You Ready? Retrieved from https://medium.com/the-edtech-world/edtech-trends-2018-5be1d42c8f37

Yuan, D. (2017, May). Developing hands-on cybersecurity laboratory with virtualization. Journal of Computing Sciences in Colleges, 32(5), 118-124. Retrieved from http://dl.acm.org/citation.cfm?id=3069649 